\title{
PALEOENVIRONMENT AND TAPHONOMY OF THE DINOSAUR-BEARING ISCHIGUALASTO FORMATION (UPPER TRIASSIC, ARGENTINA)
}

ROGERS*, Raymond R., Dept. Geophysical Sciences, University of Chicago, Chicago, IL 60637, U.S.A.; FORSTER, Catherine A., Dept. Organismal Biology and Anatomy, University of Chicago, Chicago, IL 60637, U.S.A.; MAY, Cathleen L., Dept. Organismal Biology and Anatomy, University of Chicago, Chicago, IL 60637, U.S.A.; MONETTA, Alfredo, Museo de Ciencias Naturales, San Juan 5400, ARGENTINA; SERENO, Paul C., Dept. Organismal Biology and Anatomy, University of Chicago, Chicago, IL 60637, U.S.A.

The oldest-known dinosaurs (Herrerasaurus, Pisanosaurus) occur within the Ischigualasto Formation. Recent work in the formation has brought to light significant new material, including the complete skeleton of a new primitive dinosaur. We sketch below the paleoenvironment and faunal succession during the range of these early dinosaurs, and review some of the taphonomic factors that shaped their fossil record.

The Ischigualasto Formation (Carnian?) is included within the Agua de la Peña Group, a series of continental Triassic deposits exposed in the Ischigualasto-Ville Union Basin of northwest Argentina. Ischigualasto sediments rest unconformably upon the carbonaceous fluvial/lacustrine Los Rastros Formation; this contact is characterized locally by marked angular discordance. The upper contact is gradational into red-beds of the Los Colorados Formation. Medium- to coarse-grained conglomeratic sandstones, siltstones, and silty mudstones dominate the section. Sand bodies are characterized by medium- to large-scale trough cross-stratification and broad lenticular/narrow sheet geometries, and are interpreted as deposits of shallow, low-sinuosity streams. Siltstones and mudstones show pervasive evidence of soil development, including root traces, nodular caliche horizons, and pedogenic slickensides. Deposits attributable to lacustrine/paludal sedimentation are scarce, and freshwater vertebrates and invertebrates are extremely rare. These data suggest an upland depositional setting on a low-relief alluvial plain with seasonal climate.

The Ischigualasto vertebrate fauna includes archosaurs, rhynchosaurs, traversodontid and carnivorous cynodonts, and temnospondyl amphibians. Rhynchosaurs dominate (relative specimen abundance) in the lower half of the section, but are absent from the upper half. Traversodontid cynodonts occur throughout the formation, but are much more abundant up-section. Archosaurs, carnivorous cynodonts, and particularly temnospondyls are rare throughout, with dinosaurs limited to the lower half. No major stratigraphic or sedimentologic changes occur up-section, and there is no evidence for significant shifts in physical or chemical taphonomic processes. Thus, trends in relative taxon abundance likely record a true biotic signal (e.g., local extinction, immigration) rather than a taphonomically-driven preservational bias.

Fossils are preserved as isolated carcasses or disarticulated elements, most often in fine-grained overbank facies. Bone beds and microsites are conspicuously absent. Temnospondyl remains were found within a local carbonaceous lens developed upon a sand body, suggesting autochthonous burial in an abandoned-channel setting. Isolated skulls, particularly those of the traversodontid Exaeretodon, are extremely common. Fifteen isolated crania of this cynodont were mapped in a single stratum with limited areal exposure. Abundant preservation of isolated therapsid crania has also been reported in the Beaufort Series (Permo-Triassic) of the Karoo Basin, South Africa (Smith, 1980). Post-disarticulation hydrodynamic sorting (enhanced by scavenging?) of an areally dispersed mass-mortality assemblage may explain this unusual occurrence.

Smith, R. M. H. 1980. The lithology, sedimentology, and taphonomy of flood-plain deposits of the Lower Beaufort (Adelaide Subgroup) strata near Beaufort West. Transactions of the Geological Socicty of South Africa, 83:399-413. 